\title{
Pengaruh Likuiditas, Profitabilitas, Struktur Modal, dan Harga Saham terhadap Kebijakan Dividen pada Perusahaan Consumer Goods
}

\author{
Nina Purnasari ${ }^{1}$ \\ Fakultas Ekonomi \\ Vivian William ${ }^{3}$ \\ Fakultas Ekonomi \\ Universitas Prima Indonesia, Indonesia
}

Sylvia ${ }^{2}$

Fakultas Ekonomi

Universitas Prima Indonesia, Indonesia Universitas Prima Indonesia, Indonesia

Surel : ninaunpri@gmail.com

\section{ABSTRAK}

Tujuan penelitian adalah mengetahui dan menganalisis pengaruh likuiditas, profitabilitas, struktur modal dan harga saham terhadap kebijakan dividen pada Perusahaan Consumer Goods yang terdaftar di Bursa Efek Indonesia Periode 2014-2018. Penelitian ini menggunakan penelitian kuantitatif. Pendekatan penelitian kuantitatif. Sifat penelitian berupa hubungan kausal. Pengumpulan data penelitian ini dengan cara dokumentasi. Populasi penelitian ini adalah 51 Perusahaan Consumer Goods yang terdaftar di Bursa Efek Indonesia Periode 2014-2018. Sampel penelitian sebanyak 16 Perusahaan Consumer Goods yang terdaftar di Bursa Efek Indonesia Periode 2014-2018. Model penelitian adalah regresi linear berganda. Hasil penelitian ini adalah Likuiditas, profitabilitas, struktur modal dan harga saham secara simultan dan parsial berpengaruh terhadap kebijakan dividen pada Perusahaan Consumer Goods.

Kata Kunci: Likuiditas; Profitabilitas; Struktur Modal; Harga Saham; Kebijakan Dividen.

Effect of Liquidity, Profitability, Capital Structure, and Share Price on Dividend Policy on Consumer Goods Companies

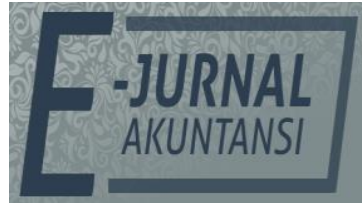

e-ISSN 2302-8556

Vol. 30 No. 12

Denpasar, Desember 2020

Hal. 3240-3251

DOI:

10.24843/EJA.2020.v30.i12.p19

PENGUTIPAN:

Purnasari, N., Sylvia, \& Wiliam, V. (2020). Pengaruh

Likuiditas, Profitabilitas, Struktur Modal, dan Harga Saham terhadap Kebijakan Dividen pada Perusahaan

Consumer Goods. E-Jurnal Akuntansi, 30(12), 3240-3251

RIWAYAT ARTIKEL: Artikel Masuk: 19 Oktober 2020 Artikel Diterima: 14 Desember 2020

liquidity, profitability, capital structure and share price on dividend policy on Consumer Goods Companies listed on the Indonesia Stock Exchange period 2014-2018. This research uses quantitative research. Quantitative research approach. The nature of research is a causal relationship. The collection of this research data by means of documentation. The population of this study is 51 Consumer Goods Companies listed on the Indonesia Stock Exchange for the period 20142018. A research sample of 16 Consumer Goods Companies listed on the Indonesia Stock Exchange period 2014-2018. The research model is multiple linear regressions. The results of this study are Liquidity, profitability, capital structure and share price simultaneously and partially affect the dividend policy on Consumer Goods Companies.

Keywords: $\quad$ Liquidity, Profitability; Capital Structure; Share Price; Dividend Policy.

Artikel dapat diakses : https://ojs.unud.ac.id/index.php/Akuntansi/index 


\section{PENDAHULUAN}

Industri barang konsumsi termasuk sektor industry dalam perusahaan konsumer mencakup minuman makanan,obat, komestik, jenis rokok dan keperluan peralatan rumahtangga. Sekarang ini permintaan atas barang konsumsi termasuk stabil sesuai dengan daya beli masyarakat. Namun beberapa tahun terakhir ini industri barang konsumsi mengalami perlambatan disebabkan persaingan yang ketat yang melibatkan industri barangkonsumsi lokal dan impor.

Tujuan utama dari perusahaan consumer goods adalah untuk mendapat laba. Dimana keseluruhan laba tersebut tidak hanya untuk pendanaan atas kegiatan operasional. Pemeriksaan atas relevansi laba ditahan ini kemudian diinvestasikan kembali dengan laba pemegang saham dalam bentuk dividen. Biasanya dividen ini akan dilakukan pembagiannya dengan melakukan kebijakan dividen. Dalam pembagian dividen ini adanya laba yang dibagikan kepada para pemegang saham baik dividen tunai maupun dividen saham.

Likuiditas ini mempergunakan keseluruhan aset lancar yang dimilikinya untuk melakukan pembayaran hutang lancar yang terjadi perusahaan. Namun perusahaan sering menghadapi masalah likuiditas dimana likuiditas yang dimilikinya rendah sehingga kemampuan membayar hutang lancar rendah memberikan dampak pada perusahaan membagikan dividen rendah bahkan tidak membagihan dividen. Adapun perusahaan yang memiliki likuiditas yang tinggi akan membagikan dividen yang tinggi disebabkan perusahaan mampu membayarkan keseluruhan hutang lancar sehingga dananya tersedia untuk dibagikan kepada pemegang saham.

Menurut Fahmi (2013:80) "profitabilitas termasuk salah satu rasio yang mampu mengukur besar kecilnya laba perusahaan yang berkaitan dengan penjualan dan investasi." Dalam hal ini perusahaan sering menghadapi masalah laba yang naik turun yang mengakibatkan kebijakan dividen yang dibagikan juga naik turun bahkan tidak membagikan dividen. Pihak manajemen dalam hal ini akan menggunakan laba tersebut dijadikan laba ditahan dan labaini digunakan pihakmanajemen untuk diberikan kepada pemegang saham.

Perusahaan memiliki struktur modal yang berasal dari modal sendiri dan modal dari luar. Namun kebanyakan perusahaan memiliki struktur modal dari luar tinggi seperti hutang sehingga mempengaruhi laba perusahaan yang akhirnya berdampak pada pembagian dividen. Perusahaan yang memiliki struktur modal hutang tinggi maka dividen yang dibagikan kepada pemegang saham relatif rendah.

Kegiatan pendanaan dari luar ini tidak terlepas dari penerbitan saham yang akan diperjualbelikan di pasar modal. Harga saham yang tinggi diakibatkan permintaan konsumen yang tinggi terhadap saham perusahaan. Namun perusahaan kebanyakan menghadapi harga saham rendah dimana permintaan saham perusahaan yang rendah. Harga saham yang tinggi dapat meningkatkan perusahaan membagikan dividen namun harga saham rendah mengakibatkan perusahaan membagikan dividen rendah.

Menurut Gumanti (2013:83) likuiditas tinggi maka dividen yang dibagikan kepada pemegang saham rendah. Menurut Rodoni \& Ali (2014:117) likuiditas rendah kemungkinan perusahaant tidak membagikan dividen. 
Maulidah dan Azhari (2015:2597) menyatkan likuiditas baik yang diukur rasio lancar sehingga kemungkinan pembayaran dividen juga baik. Indrawan, Suyanto dan Mulyadi (2017:5) menyatakan semakin tingginya rasio kas sehingga perusahaan membayar dividen yang diharapkan para investor. Hipotesis di dalam penelitian ini adalah.

$\mathrm{H}_{1}$ : Likuiditas berpengaruh negatif terhadap kebijakan dividen pada perusahaan Consumer Goods.

Akmal, Zainudin, \& Yulianti (2016:27) menyatakan ROA tinggi maka pembayaran dividen tinggi dikarenakan perusahaan memiliki kinerja yang baik.Menurut Gumanti (2013:86) laba yang tinggi maka semakin besar dividen yang dibagikan kepada pemegang saham. Menurut Husnan dan Pudjiastuti (2015:310) perusahaan membayar dividen yang tinggi jika terjadi naiknya laba dan harga saham. Maka hipotesis kedua di dalam penelitian ini sebagai berikut. $\mathrm{H}_{2}$ : Profitabilitas berpengaruh negatif terhadap kebijakan dividen pada perusahaan Consumer Goods.

Menurut Nidar (2016:264) dividen dibayarkan perusahaan jika hutang terpenuhi. Adapun pendapat yang dikemukakan oleh Akmal, Zainudin \& Yulianti (2016:27) hutang tinggi terjadi diperusahaan mempengaruhi pembayaran dividen menjadi rendah. Menurut Gumanti (2013:83) apabila hutang tinggi maka dividen yang dibayarkan rendah. Hipotesis ketiga di dalam penelitian ini sebagai berikut.

$\mathrm{H}_{3}$ : Struktur modal berpengaruh negatif terhadap kebijakan dividen pada perusahaan Consumer Goods.

Nugroho (2016:6) menyatakan harga saham tinggi maka dividen yang dibayarkan juga tinggi. Menurut Harahap (2011:152) kenaikan harga saham ini berdampak pada laba tinggi dan membagikan dividen yang tinggi kepada pemegang saham. Menurut Magaretha (2011:6) besarnya dividen yang dibayarkan perusahaan terjadinya kenaikan harga saham. Maka hipotesis keempat di dalam penelitian ini sebagai berikut.

H4 : Harga saham berpengaruh positif terhadap kebijakan dividen pada perusahaan Consumer Goods.

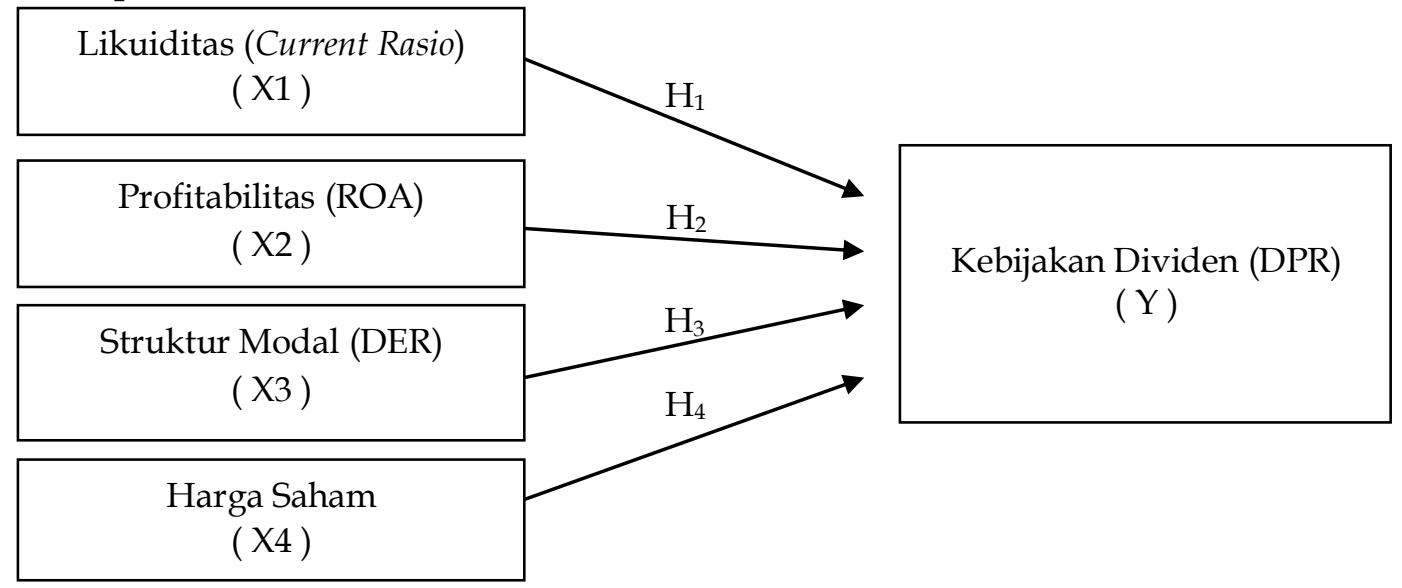

Sumber: Data Penelitian, 2020

Gambar 1. Model Peneltian 


\section{METODE PENELITIAN}

Pada penelitian ini memanfaatkan metode penelitian kuantitatif. Sifat penelitian berupa hubungan kausal dengan adanya hubungan variabel independen berpengaruh terhadap variable dependen. Data dikumpulkan cara dokumentasi dimana data yang dibutuhkan perusahaan berupa perusahaan consumer goods yang terdaftar di Bursa Efek Indonesia Periode 2014-2018 dapat dibrowsing di situs www.idx.co.id. Metode yang digunakan di dalam penelitian ini adalah metode purposive sampling. Berdasarkan data dari BEI perusahaan Consumer Goods terdapat 41 perusahaan. Sampel perusahaan yang memnuhi kriteria sebanyak 18 perusahaan dikalikan 5 tahun periode sehingga sampel observasi pengamatan sebanyak 90 laporan keuangan Perusahaan Consumer Goods yang terdaftar di Bursa Efek Indonesia Periode 2014-2018.

Likuiditas yaitu rasio yang menunjukkan kemampuan perusahaan dalam memenuhi kewajiban jangka pendeknya (Rangkuti, 2012:333). Pengukuran likuiditas dalam penelitian ini menggunakan Indikator current ratio. Profitabilitas merupakan rasio keuntungan yang mengukur seberapa besar kemampuan perusahaan memperoleh laba dalam hubungan dengan penjualan, aktiva maupun laba dan modal sendiri (Fahmi, 2014:81). Pengukuran profitabilitas dalam penelitian ini menggunakan indikator Return On Assets (ROA). Struktur modal adalah bagaimana pengaruh struktur modal terhadap nilai perusahaan, biaya modal perusahaan dan harga pasar saham (Sudana, 2015:164). Pengukuran struktur modal yang dipakai dalam penelitian ini menggunakan indikator Debt to Equity Ratio (DER). Harga saham merupakan harga yang terjadi di pasar bursa pada saat tertentu dan harga saham tertentu dilakukan oleh pelaku pasar (Priatinah, 2012:52). Indikator pengukuran harga saham adalah penutupan harga saham tahunan. Kebijakan dividen adalah penentuan tentang berapa besarnya laba yang diperoleh dalam suatu periode akan dibagikan kepada pemegang saham dalam bentuk dividen, dan akan ditahan di perusahaan dalam bentuk laba ditahan (Halim, 2015:135). Pengukuran kebijakan dividen dalam penelitian ini menggunakan indikator Dividend Payout Ratio (DPR).Teknik analisis data yang digunakan menggunakan teknik analisis regresi linier berganda. Analisis regresi linear berganda menunjukkan variabel penelitian ini lebih dari satu variabel independen dengan persamaan sebagai berikut.

$$
Y=\alpha+\beta_{1} X_{1}+\beta_{2} X_{2}+\beta_{3} X_{3}+\beta_{4} X_{4+} \varepsilon
$$

Keterangan :

$\begin{array}{ll}\mathrm{Y} & =\text { Kebijakan Dividen } \\ \mathrm{a} & =\text { Konstanta } \\ \mathrm{X}_{1} & =\text { Likuiditas } \\ \mathrm{X}_{2} & =\text { Profitabilitas } \\ \mathrm{X}_{3} & =\text { Struktur Modal } \\ \mathrm{X}_{4} & =\text { Harga Saham } \\ \beta_{1,2,3,4} & =\text { Besaran koefisien regresi dari masing -masing variabel } \\ \varepsilon & =\text { error }\end{array}$


Sebelum melakukan uji hipotesis terlebih dahulu harus melakukan uji asumsi klasik. Dalam uji asumsi klasik ini mencakup uji normalitas, uji multikolineritas, uji autokorelasi dan uji heterokedastisitas. Pengujian hipotesis yang dipakai dalam penelitian ini mencakup pengujian secara parsial (Uji t), pengujian secara simultan (Uji F), dan koefisien determinasi $\left(R^{2}\right)$.

\section{HASIL DAN PEMBAHASAN}

Statistik deskriptif dalam penelitian ini memberikan gambaran mengenai data yang tersaji seperti nilai minimum, nilai maksimum, nilai rata-rata (mean) dan standar deviasi.

\section{Tabel 1. Statistik Deskriptif}

\begin{tabular}{cccccc}
\hline & $\mathrm{N}$ & Minimum & Maximum & Mean & Std. Deviation \\
\hline CR & 80 & .58 & 8.64 & 2.7361 & 1.84636 \\
ROA & 80 & 2.76 & 52.67 & 15.1235 & 11.95520 \\
DER & 80 & .07 & 3.03 & .7999 & .64846 \\
Harga & 80 & 284.00 & 390000.00 & 17525.0250 & 47503.31416 \\
Saham & & .00 & 2.46 & .4552 & .35627 \\
DPR & 80 & & & & \\
Valid N & 80 & & & & \\
(listwise) & & & & & \\
\hline
\end{tabular}

Berdasarkan Tabel 1, menunjukkan Jumlah sampel likuiditas 80 dengan nilai minimum 0,58 dan nilai maximum 8,64 sedangkan nilai mean 2,7361 serta standar deviasi 1,84636.Jumlah sampel profitabilitas 80 dengan nilai minimum 2,76 dan nilai maximum 52,67 sedangkan nilai mean 15,1235 serta standar deviasi 11,95520. Jumlah sampel struktur modal 80 dengan nilai minimum 0,07 dan nilai maximum 3,03 sedangkan nilai mean 0,7999 serta standar deviasi 0,64846.

Jumlah sampel harga saham 80 dengan nilai minimum 284,00 dan nilai maximum 390.000,00 sedangkan nilai mean 17.525,0250 serta standar deviasi 47.503,31416.Jumlah sampel kebijakan dividen 80 dengan nilai minimum 0,00 dan nilai maximum 2,46 sedangkan nilai mean 0,4552 serta standar deviasi 0,35627 .

Tabel 2. One-Sample Kolmogorov-Smirnov Test

\begin{tabular}{llr}
\hline & & Unstandardized Residual \\
\hline $\mathrm{N}$ & & 75 \\
Normal Parametersa,b & Mean & .0000000 \\
& Std. & .46465635 \\
& Deviation & \\
Most Extreme Differences & Absolute & .077 \\
& Positive & .070 \\
Test Statistic & Negative & -.077 \\
Asymp. Sig. (2-tailed) & & .077 \\
\hline
\end{tabular}

Sumber: Data Penelitian, 2020

Berdasarkan Tabel 2, uji normalitas dengan dengan nilai sig 0,200>0,05 memenuhi syarat distribusi normal. 
Tabel 3. Hasil Uji Multikolinieritas

\begin{tabular}{llcc}
\hline \multicolumn{2}{c}{ Model } & \multicolumn{3}{c}{$\begin{array}{c}\text { Collinearity } \\
\text { Statistics }\end{array}$} \\
\cline { 3 - 4 } & & Tolerance & VIF \\
\hline 1 & (Constant) & .400 & 2.497 \\
& Ln_CR & .667 & 1.499 \\
& Ln_ROA & .345 & 2.899 \\
Ln_DER & .578 & 1.730 \\
& Ln_HargaSaham & &
\end{tabular}

Berdasarkan Tabel 3, menunjukkan nilai tolerance variabel likuiditas, profitabilitas, struktur modal dan harga saham lebih besar dari 0,1 dapat disimpulkan bahwa tidak terjadi multikolinearitas. likuiditas, profitabilitas, struktur modal dan harga saham memiliki nilai tolerance lebih kecil dari 0,1 disimpulkan bahwa tidak terjadi multikolinearitas.

Tabel 4. Hasil Uji Glejser

\begin{tabular}{llrrrrr}
\hline Model & \multicolumn{2}{l}{$\begin{array}{l}\text { Unstandardized } \\
\text { Coefficients }\end{array}$} & \multicolumn{2}{c}{$\begin{array}{c}\text { Standardized } \\
\text { Coefficients }\end{array}$} & \multirow{2}{*}{$\mathrm{t}$} & \multirow{2}{*}{ Sig. } \\
\cline { 3 - 5 } & \multicolumn{1}{c}{ B } & Std. Error & Beta & & \\
\hline 1 & (Constant) & .514 & .215 & & 2.392 & .019 \\
& Ln_CR & -.114 & .087 & -.242 & -1.319 & .191 \\
& Ln_ROA & -.038 & .061 & -.090 & -.633 & .529 \\
& Ln_DER & -.005 & .068 & -.014 & -.073 & .942 \\
& Ln_Harga & .001 & .029 & .004 & .027 & .979 \\
& Saham & & & & & \\
\end{tabular}

a. Dependent Variable: Abs_ut1

Sumber: Data Penelitian, 2020

Tabel 4, menunjukkan nilai signifikan variabel likuiditas, profitabilitas, struktur modal dan harga saham berada di atas 0,05 disimpulkan tidak terjadi heteroskedastisitas.

Tabel 5. Hasil Uji Autokorelasi

\begin{tabular}{ccrrrrr} 
Model & $\mathrm{R}$ & $\mathrm{R}$ Square & $\begin{array}{c}\text { Adjusted } \mathrm{R} \\
\text { Square }\end{array}$ & $\begin{array}{c}\text { Std. Error of } \\
\text { the Estimate }\end{array}$ & Durbin-Watson \\
\hline 1 & $.699 \mathrm{a}$ & .488 & .459 & .47775 & 2.198
\end{tabular}

a. Predictors: (Constant), Ln_HargaSaham, Ln_CR, Ln_ROA, Ln_DER

b. Dependent Variable: Ln_DPR

Sumber: Data Penelitian, 2020

Dari Tabel 5, menunjukkan bahwa nilai DW yang diperoleh adalah sebesar 2,198. Cara pengukuran uji autokorelasi adalah $\mathrm{du}<\mathrm{d}<4-\mathrm{du}$. Nilai $\mathrm{dL}$ dan du dalam penelitian ini dengan jumlah 4 variabel dan 75 sampel adalah $\mathrm{dl}=$ $1,5151$ dan $\mathrm{du}=1,7390$. Hasil pengukurannya adalah 1,7390<2,198< $<4-1,7390)$ yaitu $1,7390<2,198<2,261$. Berdasarkan hasil ini menunjukkan tidak terjadi autokorelasi. 
Tabel 6. Hasil Analisis Regresi Linier Berganda

\begin{tabular}{|c|c|c|c|c|c|c|}
\hline & \multirow[t]{2}{*}{ Model } & \multicolumn{2}{|c|}{$\begin{array}{l}\text { Unstandardized } \\
\text { Coefficients }\end{array}$} & \multirow{2}{*}{$\begin{array}{c}\begin{array}{c}\text { Standardized } \\
\text { Coefficients }\end{array} \\
\text { Beta }\end{array}$} & \multirow[t]{2}{*}{$\mathrm{t}$} & \multirow[t]{2}{*}{ Sig. } \\
\hline & & B & Std. Error & & & \\
\hline \multirow[t]{5}{*}{1} & (Constant) & -2.829 & .333 & & -8.491 & .000 \\
\hline & Ln_CR & -.380 & .134 & -.382 & -2.829 & .006 \\
\hline & Ln_ROA & .304 & .094 & .338 & 3.232 & .002 \\
\hline & Ln DER & -.474 & .105 & -.656 & -4.503 & .000 \\
\hline & Ln_HargaSaham & .148 & .044 & .376 & 3.343 & .001 \\
\hline
\end{tabular}

a. Dependent Variable: Ln_DPR

Sumber: Data Penelitian, 2020

Berdasarkan Tabel 6, diperoleh rumus regresi sebagai berikut.

Ln_DPR $=-2,829-0,380$ Ln_CR + 0,304 Ln_ROA - 0,474 Ln_DER + 0,148 Ln_Harga Saham

Nilai a sebesar $-2,829$ artinya jika variabel likuiditas, profitabilitas, struktur modal dan harga saham dianggap konstan, maka kebijakan dividen adalah sebesar $-2,829$.

Nilai koefisien likuiditas adalah -0,380. Ini menunjukkan bahwa setiap peningkatan likuiditas satu kali maka kebijakan dividen akan mengalami penurunan sebesar 0,380 .

Nilai koefisien profitabilitas sebesar 0,304. Ini menunjukkan bahwa setiap peningkatan profitabilitas satu kali maka kebijakan dividen akan mengalami peningkatan sebesar 0,304.

Nilai koefisien struktur modal sebesar -0,474. Ini menunjukkan bahwa setiap peningkatan struktur modal satu kali maka kebijakan dividen akan mengalami penurunan sebesar 0,474.

Nilai koefisien harga saham sebesar 0,148. Ini menunjukkan bahwa setiap peningkatan harga saham satu kali maka kebijakan dividen akan mengalami peningkatan sebesar 0,148.

\section{Tabel 7. Hasil Uji Statistik F}

\begin{tabular}{llrrrrr}
\hline Model & $\begin{array}{c}\text { Sum of } \\
\text { Squares }\end{array}$ & df & \multicolumn{1}{c}{$\begin{array}{l}\text { Mean } \\
\text { Square }\end{array}$} & F & Sig. \\
\hline 1 & Regression & 15.246 & 4 & 3.811 & 16.699 & $.000^{\mathrm{b}}$ \\
& Residual & 15.977 & 70 & .228 & & \\
Total & 31.223 & 74 & & & \\
\hline
\end{tabular}

a. Dependent Variable: Ln_DPR

b. Predictors: (Constant), Ln_HargaSaham, Ln_CR, Ln_ROA, Ln_DER

Sumber: Data Penelitian, 2020

Dari Tabel 7, bisa dilihat hasil $F_{\text {hitung }}$ adalah sebesar 16,699 dengan nilai signifikan 0,000 sedangkan $F_{\text {tabel }} \quad(75-5=70)$ adalah sebesar 2,50 maka kesimpulannya adalah $F_{\text {hitung }}>F_{\text {tabel }}$ yaitu 16,699 $>2,50$ sehingga keputusannya adalah Ho ditolak dan Ha diterima, artinya variabel Likuiditas, profitabilitas, struktur modal dan harga saham berpengaruh terhadap kebijakan dividen pada Perusahaan Consumer Goods yang terdaftar di Bursa Efek Indonesia Periode 20142018. 
Tabel 8. Koefisien Determinasi

\begin{tabular}{ccccc}
\hline Model & $\mathrm{R}$ & $\mathrm{R}$ Square & $\begin{array}{c}\text { Adjusted } \mathrm{R} \\
\text { Square }\end{array}$ & $\begin{array}{c}\text { Std. Error of the } \\
\text { Estimate }\end{array}$ \\
\hline 1 & $.699^{\mathrm{a}}$ & .488 & .459 & .47775 \\
\hline
\end{tabular}

a. Predictors: (Constant), Ln_HargaSaham, Ln_CR, Ln_ROA, Ln_DER

b. Dependent Variable: Ln_DPR

Sumber: Data Penelitian, 2020

Berdasarkan Tabel 8, diperoleh nilai adjusted $R$ Square $\left(\mathrm{R}^{2}\right)$ koefisien determinasi sebesar 0,459 atau sama dengan 45,9\%. variabel independen berpengaruh terhadap kebijakan dividen sebesar 45,9\% dan sisanya 54,1\% dipengaruhi variabel lain seperti laba bersih, arus kas, leverage.

Tabel 9. Koefisien Determinasi

\begin{tabular}{llrrrrr}
\hline \multirow{2}{*}{ Model } & \multicolumn{2}{c}{ Unstandardized Coefficients } & $\begin{array}{c}\text { Standardized } \\
\text { Coefficients }\end{array}$ & $\mathrm{t}$ & Sig. \\
\cline { 3 - 5 } & \multicolumn{1}{c}{$\mathrm{B}$} & \multicolumn{1}{c}{ Std. Error } & \multicolumn{1}{c}{ Beta } & & \\
\hline 1 & (Constant) & -2.829 & .333 & & -8.491 & .000 \\
& Ln_CR & -.380 & .134 & -.382 & -2.829 & .006 \\
& Ln_ROA & .304 & .094 & .338 & 3.232 & .002 \\
& Ln_DER & -.474 & .105 & -.656 & -4.503 & .000 \\
& Ln_HargaSaham & .148 & .044 & .376 & 3.343 & .001 \\
\hline
\end{tabular}

a. Dependent Variable: Ln_DPR

Sumber: Data Penelitian, 2020

Tabel 9, menunjukkan variabel likuiditas mempunyai nilai $t_{\text {hitung }}$ adalah sebesar -2,829 dengan nilai signifikan 0,006 sedangkan $t_{\text {tabel }}(75-4=71)$ adalah sebesar 1,993 dan nilai signifikan 0,006 di bawah signifikan 0,05 sehingga kesimpulannya adalah $-t_{\text {hitung }}<-t_{\text {tabel }}$ yaitu $-2,829<-1,993$ maka keputusannya adalah Ho diterima dan $\mathrm{H}_{\mathrm{a}}$ ditolak, artinya variabel Likuiditas berpengaruh terhadap kebijakan dividen pada Perusahaan Consumer Goods yang terdaftar di Bursa Efek Indonesia Periode 2014-2018.

Variabel profitabilitas mempunyai nilai thitung 3,232 dengan nilai signifikan 0,002 sedangkan $t_{\text {tabel }}$ adalah sebesar 1,993 dan nilai signifikan 0,002 berada di bawah signifikan 0,05 maka kesimpulannya adalah $t_{\text {hitung }}>t_{\text {tabel }}$ yaitu 3,232>1,993 sehingga keputusannya adalah Ho ditolak dan $\mathrm{H}_{\mathrm{a}}$ diterima, artinya variabel profitabilitas berpengaruh terhadap kebijakan dividen pada Perusahaan Consumer Goods yang terdaftar di Bursa Efek Indonesia Periode 2014-2018.

Variabel struktur modal mempunyai nilai thitung $-4,503$ dengan nilai signifikan 0,000 sedangkan $t_{\text {tabel }}$ adalah sebesar 1,993 dan nilai signifikan 0,000 berada di bawah signifikan 0,05 maka kesimpulannya adalah - thitung $_{<}-\mathrm{t}_{\text {tabel }}$ yaitu $-4,503$ sehingga keputusannya adalah Ho diterima dan $\mathrm{H}_{\mathrm{a}}$ ditolak, artinya variabel struktur modal berpengaruh terhadap kebijakan dividen pada Perusahaan Consumer Goods yang terdaftar di Bursa Efek Indonesia Periode 2014-2018.

Variabel harga saham mempunyai nilai thitung adalah sebesar 3,343 dengan nilai signifikan 0,001 sedangkan $t_{\text {tabel }}$ sebesar 1,993 dan nilai signifikan 0,001 di bawah signifikan 0,05 sehingga kesimpulannya adalah $t_{\text {hitung }}<t_{\text {tabel }}$ yaitu 3,343 > 1,993 maka keputusannya adalah Ho ditolak dan $\mathrm{H}_{\mathrm{a}}$ diterima , artinya variabel harga saham berpengaruh terhadap kebijakan dividen pada Perusahaan Consumer Goods yang terdaftar di Bursa Efek Indonesia Periode 2014-2018. 


\section{SIMPULAN}

Berdasarkan pada hasil penelitian, maka dapat ditarik beberapa simpulan sebagai berikut likuiditas berpengaruh terhadap kebijakan dividen pada Perusahaan Consumer Goods yang terdaftar di Bursa Efek Indonesia Periode 20142018. Profitabilitas berpengaruh terhadap kebijakan dividen pada Perusahaan Consumer Goods yang terdaftar di Bursa Efek Indonesia Periode 2014-2018. Struktur modal berpengaruh terhadap kebijakan dividen pada Perusahaan Consumer Goods yang terdaftar di Bursa Efek Indonesia Periode 2014-2018. Harga saham berpengaruh terhadap kebijakan dividen pada Perusahaan Consumer Goods yang terdaftar di Bursa Efek Indonesia Periode 2014-2018. Likuiditas, profitabilitas, struktur modal dan harga saham berpengaruh terhadap kebijakan dividen pada Perusahaan Consumer Goods yang terdaftar di Bursa Efek Indonesia Periode 2014-2018.

\section{REFERENSI}

Akmal, Zainudin, \& Rahmah Yulianti. (2016). Pengaruh Return on Asset, Sales Growth, Firm Size Dan Debt To Equity Ratio Terhadap Pembayaran Dividen Pada Perusahaan Manufaktur Sub Sektor Perusahaan Makanan Dan Minuman Yang Terdaftar Di Bursa Efek Indonesia Periode 20102014. Ekonomi Manajemen Dan Akuntansi, 2(2), 24-36.

Fahmi, Irham. (2012). Pengantar Manajemen Keuangan. Bandung : Penerbit Alfabeta.

Fahmi, Irham. (2013). Pengantar Manajemen Keuangan Teori dan Soal Jawab. Bandung: Alfabeta.

Fahmi, Irham. (2014). Pengantar Manajemen Keuangan Teori dan Soal Jawab. Bandung: Alfabeta.

Gumanti, Tatang Ary. (2013). Kebijakan Deviden. Jakarta : Penerbit UPP STIM YKPN

Harahap, A. (2011). Pengaruh Earning Per Share Dan Harga Saham Terhadap Dividen Kas Perusahaan Manufaktur Di Bursa Effek Indonesia Tahun 2006-2008. Jurnal Manajemen Dan Bisnis Universitas Bandar Lampung, 1(2), 111486.

Halim, Abdul. (2015). Manajemen Keuangan Bisnis Konsep dan Aplikasinya. Jakarta : Mitra Wacana Media

Husnan, Suad dan Pudjiastuti. (2015). Dasar-dasar Manajemen Keuangan. Edisi Ketujuh. Yogyakarta : Unit Penerbit dan Percetakan (UPP STIM YKPN).

Kurniawan, E. R., Arifati, R., \& Andini, R. (2016). Pengaruh Cash Position, Debt Equity Ratio, Return on Asset, Current Ratio, Firm Size, Price Earning Ratio, Dan Total Assets Turn Over Terhadap Deviden Payout Ratio Pada Perusahaan Manufaktur Periode 2007-2014. Journal Of Accounting Universitas Pandanaran, 2(2), 1-13.

Kasmir. (2014). Analisis Laporan Keuangan. Jakarta : Penerbit Rajagrafindo Persada. 
Margaretha, Farah. (2011). Manajemen Keuangan Untuk Manajer Non keuangan. Jakarta : Penerbit Erlangga.

Maulidah, F., \& Azhari, M. (2015). Pengaruh Return On Asset, Current Ratio , Debt To Total Asset Ratio , Growth Dan Firm Size Terhadap Divident Payout Ratio ( Studi Pada Perusahaan BUMN yang Terdaftar di BEI Tahun 2009-2013 ). E-Proceeding of Management Universitas Telkom, 2(3), 2595-2602.

Nidar, Sulaeman Rahman. (2016). Manajemen Keuangan Perusahaan Modern. Cetakan Pertama. Bandung : Penerbit Pustaka Reka Cipta.

Rodoni, Ahmad dan Ali, Herni. (2014). Manajemen Keuangan Modern. Jakarta : Penerbit Mitra Wacana Media

Sitanggang, J.P. (2012). Manajemen Keuangan Perusahaan. Jakarta : Penerbit Mitra Wacana Media

Sudana, I Made. (2015) Teori E Praktik Manajemen Keuangan Perusahaan. Jakarta : Erlangga.

Sugiyono. (2014). Metode Penelitian Manajemen. Bandung : Alfabeta.

Wijayanto. (2012). Pengantar Manajemen. Jakarta : Penerbit Pt Gramedia Pustaka Utama.

Widioatmodjo, Sawidji. (2012). Cara Sehat Investasi Di Pasar Modal. Edisi Revisi. Jakarta : PT Elex Media Komputindo.

Abbas, A., Hashmi, S. H., \& Chishti, A. F. (2017). Dividend Policy and Capital Structure: Testing Endogeneity. SSRN Electronic Journal.

Ahmed, I. E. (2015). Liquidity, Profitability and the Dividends Payout Policy. World Review of Business Research, 5(2), 73-85.

Dewi, N., \& Sedana, I. (2014). Pengaruh Struktur Modall, Likuiditas Dan Pertumbuhan Terhadap Kebijakan Deviden Di Bei. E-Jurnal Manajemen Universitas Udayana, 3(6), 254804.

Elizabeth, W. M. (2015). The effect of profitability on dividend policy of commercial bnaks in Kenya. 1-78.

Esfahani, A. Z., \& Jaffar, R. (n.d.). The Effect of Corporate Governance and Capital Structure on Dividend Payment: Evidence from Malaysia. Recent Advances in Management, Marketing and Finances, 75-80.

Fajaria, A. Z. (2018). The Effect of Profitability, Liquidity, Leverage and Firm Growth of Firm Value with its Dividend Policy as a Moderating Variable. International Journal of Managerial Studies and Research, 6(10), 55-69.

Habib, Y., Kiani, Z. I., \& Khan, M. A. (2011). Dividend Policy and Share Price Volatility in Nigeria. Jorind, 12(9), 202-210.

Janifairus, J. B., Hidayat, R., Husaini, A., Administrasi, F. I., Brawijaya, U., Growth, A., ... Ratio, D. P. (2010). Pengaruh Return on Asset, Debt To Equity Ratio , Assets Growth, Dan Cash Ratio Terhadap Dividend Payout Ratio. Jurnal Administrasi Bisnis, 1, 161-169.

Keuangan, K., Keuangan Keuangan 78, K., Keuangan, J., \& Perbankan, D. (2009). Muhammad Asril Arilaha. Jurnal Keuangan Dan Perbankan, 13(1), 78-87.

Kibet, K. P., \& Mirie, M. (2012). The Effect of Liquidity on Dividend Payout By Companies Listed at The Nairobi Securities Exchange. Journal Business Administration of the University of Nairobi, 7(8), 1-54.

Laili, M., Darmawan, N. A. S., \& Sinarwati, N. K. (2015). Pengaruh Debt To 
Equity, Kepemilikan Manajerial, Return On Assets, dan Current Ratio Terhadap Dividend Payout Ratio. E-Jurnal S1 Ak, Universitas Pendidikan Ganesha, 3(1).

Lestari, K. F., Tanuatmodjo, H., \& Mayasari, M. (2017). Pengaruh Likuiditas Dan Profitabilitas Terhadap Kebijakan Dividen. Journal of Business Management Education (JBME), 2(1), 243-250.

Marlina, L., \& Danica, C. (2009). Analisis pengaruhcash position, debt to equity ratio, dan return on assets terhdadap dividen payout ratio. Jurnal Manajemen Bisnis, 2, 1-6.

Novita Sari, K., \& Sudjarni, L. (2015). Pengaruh Likuiditas, Leverage, Pertumbuhan Perusahaan, Dan Profitabilitas Terhadap Kebijakan Dividen Pada Perusahaan Manufaktur Di Bei. E-Jurnal Manajemen Universitas Udayana, 4(10), 255134.

Nurhayati, M. (2013). Profitabilitas, likuiditas dan ukuran perusahaan pengaruhnya terhadap kebijkan dividen dan nilai perusahaan sektor non jasa. Jurnal Keuangan Dan Bisnis, 5(2), 144-153.

Parsian, H., \& Koloukhi, A. S. (2014). A study on the effect of free cash flow and profitability current ratio on dividend payout ratio: Evidence from Tehran Stock Exchange. Management Science Letters, 4, 63-70.

Sari, M. R., Oemar, A., \& Andini, R. (2016). Pengaruh pertumbuhan perusahaan, ukuran perusahaan, earning per share, current ratio, return on equity dan debt equity ratio terhadap kebijakan dividen. Journal Of Accounting, 2(2), 119.

Yudhanto, S., \& Aisjah, S. (2012). Pengaruh Net Profit Margin, Return On Asset, Return On Equity, Earning Per Share Terhadap Kebijakan Dividen (Studi pada Perusahaan Manufaktur yang Terdaftar Di Bursa Efek Indonesia). Jurnal Ilmiah Mahasiswa Fakultas Ekonomi Dan Bisnis, 1(2), 1-14.

Rizqia, D. A., Aisjah, S., Program, P., \& Java, E. (2013). Effect of Managerial Ownership, Financial Leverage, Profitability, Firm Size, and Investment Opportunity on Dividend Policy and Firm Value. 4(11), 120-130.

Gill, A., Biger, N., \& Tibrewala, R. (2010). Determinants of Dividend Payout Ratios: Evidence from United States. The Open Business Journal, 3(1), 8-14.

Hakeem, S. A., \& Bambale, A. J. (2016). Mediating Effect of Liquidity on Firm Performance and Dividend Payout of Listed Manufacturing Companies in Nigeria. Journal of Economic Development, Management, IT, Finance and Marketing, 53(9), 1689-1699.

Hasan, M., Ahmad, M. I., Rafiq, M. Y., \& Rehman, R. U. (2015). Dividend Payout Ratio and Firm's Profitability. Evidence from Pakistan. Theoretical Economics Letters, 05(03), 441-445.

Herawati, A., \& Irradha Fauzia, F. (2018). The Effect of Current Ratio, Debt to Equity Ratio and Return on Asset on Dividend Payout Ratio in Sub-sector Automotive and Component Listed in Indonesia Stock Exchange in Period 2012-2016. KnE Social Sciences, 3(10), 1076-1086.

Igan, D., de Paula, A., \& Pinheiro, M. (2010). Munich Personal RePEc Archive Liquidity and Asset Prices. Munich Personal RePEc Archive, (24768).

Issa, A. I. F. (2015). The Determinants of Dividend Policy: Evidence from Malaysian Firms. Research Journal of Finance and Accounting, 6(18), 69-87. 
PhD, M. S. B., Jinadu, A. G., \& Opeyemi, M. F. (2017). Impact Of Capital Structure On Dividend Pay-Out Ratio In Unilever Nigerian Plc. Journal of Management Sciences University of Maiduguri, 15, 61-75.

Thi, N., \& Trang, X. (2012). Determinants Of Dividend Policy The Case Of Vietnam. International Journal of Business, Economics and Law, 1, 48-57. 